\title{
Regulating Commercial Global Surrogacy: The Best Interests of the Child
}

\author{
Karen Smith Rotabi ${ }^{1}$ (D) - Susan Mapp ${ }^{2} \cdot$ Kristen Cheney $^{3} \cdot$ Rowena Fong $^{4}$ • \\ Ruth McRoy ${ }^{5}$
}

Published online: 10 June 2017

(C) Springer International Publishing 2017

\begin{abstract}
Concurrent with the decline in intercountry adoption, there has been an increase in commercial global surrogacy over the past decade, but no international law yet exists to reconcile conflicting national laws and protect the interests of infant/child, surrogate mother, and commissioning parent(s). Previous discussion has focused on the vulnerability of the surrogate mothers and insufficient attention has been given to the best interests of the child, despite the fact that some children have been left stateless for years as a result of conflicting policies. Using the principles of the Hague Convention on Intercountry Adoption, social workers and policy makers should advocate for the development of international law to regulate commercial global surrogacy in order to prevent children's rights violations and act in the best interests of the child.
\end{abstract}

Keywords Global surrogacy · Best interests of the child · Social work ethics

Intercountry adoption has been one of the primary non-biological ways to create a family, particularly for those who perceived it as a method to adopt a healthy infant/young child. However, since the Hague Convention of May 29, 1993, on Protection of Children

Karen Smith Rotabi

ksrotabi@yahoo.com

Susan Mapp

mapps@etown.edu

United Arab Emirates University, Al Ain, United Arab Emirates

2 Elizabethtown College, Elizabethtown, PA, USA

International Institute of Social Studies, The Hague, The Netherlands

4 University of Texas at Austin, Austin, TX, USA

5 Boston College, Boston, MA, USA and Co-operation in Respect of Intercountry Adoption (hereafter referred to as the Hague Convention or simply the HCIA) has come into force, the number of these adoptions has fallen drastically noticeably during the mid-2000s: There was a worldwide peak of 45,000 adoptions in 2004 but has now declined by over $70 \%$ (Selman 2015). Concurrently, there has been a rise in commercial global surrogacy (CGS) as a method to create families (Cuthbert and Fronek 2014). Commercial surrogacy is defined as, "an arrangement whereby the intending parent(s) ... pay the surrogate mother ... in excess of the actual out-of-pocket expenses" (Tobin 2014, p. 318). Sometimes referred to as a "womb for rent" in the media, commercial surrogacy is a practice in which a woman is contractually paid for the pregnancy. In many cases today, an embryo is transferred to a surrogate's uterus and she carries out the pregnancy to term; she is paid for her services as per the surrogacy legal agreement/contract (Goodwin 2009). This financial arrangement is in contrast to altruistic surrogacy in which a woman acts as a surrogate without financial gain (excepting legitimate reimbursed expenses). The practice of contracting surrogacy has raised a number of ethical issues, particularly when it occurs across borders, and debates have ensued about how to best fulfill human rights obligations to protect the vulnerable. These debates and discourse have most often focused on the surrogate mothers, with some concerns for the children conceived through these arrangements, and occasionally for those commissioning the surrogacy (see Rotabi et al. 2015a).

Social work concerns about the ethical dilemmas arising from surrogacy entered into the public discourse when The Guardian newspaper in London published a blog entitled "What social workers need to know about surrogacy" (Crawshaw 2016). In it, Crawshaw asserts that "Care workers must be well informed if they are to recognise the human rights and social work principles that need to be respected in order to practise safely and ethically" (para. 2). The piece closes with the statement, "Medical science creates 
opportunities; social workers need to ensure it does not create unnecessary dangers through surrogacy" (para. 12). As a result of this view, Crawshaw and others have committed to developing a position statement and recommendations issued by the British Association of Social Workers (BASW) on advanced reproductive technologies, to include surrogacy. This particular position statement is oriented to the best interests of the child, while considering all parties in surrogacy arrangements, including gamete (egg/sperm) donors. On this point of gamete donors, while a deep treatment of this subject is outside of the focus of this paper, however it is an oversight to not acknowledge that use of an unrelated gamete is relatively common in surrogacy transactions when the commissioning parent(s) suffer infertility, to include single individuals and gay and lesbian couples who use surrogacy to build their family with a gamete donation. It is important to note that some countries like the UK do not allow for anonymous donors as it is believed that a child has a right to know his/her origin and this is consistent with the Convention on the Rights of the Child (Art 8) which states that "every child has a right to preserve her or his identity, including nationality, name, and family relations". In the case of anonymity, it may be argued that the right to know family relations is violated as the genetic family relationship is obscured.

In countries where there is no pathway for anonymous donors, there is usually a lack of supply of gametes and individuals/couples in need of an ovum or sperm will often look to other countries to purchase their surrogacy services (where anonymous gametes are available). Indeed, there is a significant business in gametes (including top dollar being compensated for ovum/sperm of women/men donors who attend top universities, have so-called "attractive' traits, etc.). It is important to note that the term "donor" is most often a misnomer as financial transaction takes place for the gamete although there are some cases in which there is an actual donation - uncompensated gamete access is far less common as compared to the practice of selling ovum/sperm for profit. Such profits also parallel the concerns about child sales as will be discussed later in this paper.

The BASW (2016) position statement tackles exploitation directly, making the point that any and all people in the surrogacy transaction can be exploited with resulting "inequalities and injustices which should be challenged whenever they arise" (p. 2). The BASW position statement also covers the right of the child to know his/her identity when donor gametes are used and recognizes issues of nationality and parentage as points of serious child rights concerns. Prior to this 2016 BASW position statement, the International Federation of Social Work (2012) has also issued a detailed policy statement exploring the myriad of issues related to advanced reproductive technologies and cross-border surrogacy activity-their position statement has been informed by the work of the BASW.
Due to the concerns that have been raised by social work associations as well as other human rights groups, efforts prior to the 2016 BASW position statement occurred to address rights issues related to commercial global surrogacy. For example, an International Forum on Intercountry Adoption and Global Surrogacy was held in The Hague, Netherlands in 2014 (Cheney 2014a). One sub-group with expertise in intercountry adoption, human trafficking, and child rights examined issues of both intercountry adoption and CGS from a rights-based perspective (see Rotabi 2014), and this paper was written by four members of that group in addition to the forum chair.

In concordance with the Convention on the Rights of the Child (CRC), the best interests of the child is a primary consideration in child welfare (Art. 3), however the best interests principle is one that has not yet received sufficient attention in CGS. Due to the rapidly shifting legal landscape in CGS, and the fact that it is not mentioned in the CRC, it is essential that social workers have a firm grasp of the legal and ethical issues that CGS can raise and are able to advocate for protections for all involved, including the children who do not have a voice of their own (British Association of Social Workers 2016). In order to advocate for those protections, the history of intercountry adoption, as well as its ethical issues, and subsequent legal protections must be reviewed as instructive for CGS regulation. Next, the problems related to CGS in countries where this practice occurs today, particularly the United States, will be explored.

\section{The History of Intercountry Adoption and Regulation}

Intercountry adoption of children largely began as a response to the devastation of war, such as the Korean War in the 1950s (Fong et al. 2016). Intercountry adoption continued to expand, particularly as improved access to contraception, legal abortion, and societal attitudes favorable to children born out of wedlock led to a decrease in the number of domestically available healthy infants in countries of the Global North. However, as sending countries themselves began to develop, the countries from which children are available (countries of origin) have changed, as well as the number of children available (Selman 2015). Adoption shifted from a method to provide parents to a child (a human right) to a method to provide a child to parents (which is not a human right). Agencies and intermediaries began to see intercountry adoption as a significant money-maker, and ethical and social justice concerns ensued (Hollingsworth 2003).

Ethical concerns in the practice of intercountry adoption have received considerable attention in the social work literature (e.g., Rotabi and Bunkers 2011; Rotabi et al. 2015b). Overall, the profession of social work has been pragmatic in 
framing intercountry adoption and the future of the practice: a number of social work scholars have taken a clear human rights-based approach to child welfare, providing guidance to strengthen systems and thereby preserving intercountry adoption as an intervention only for the appropriate children (Roby 2007; Gibbons and Rotabi 2012). International treaties and law have framed "appropriate children" as children who truly have no humane alternative care options other than adoption, to first attempt domestic adoption in their homeland, and lastly intercountry adoption in cases where sending a child to another country becomes necessary. The Convention on the Rights of the Child (1989), Article 21, which provides a number of rights to children specific to intercountry adoption, including that it be an option only after appropriate care possibilities have been exhausted in that child's family, kinship, and community networks. In addition, the CRC supports a family preservation approach by providing the right to support the family of origin, so that the child is not separated from family members, unless there is no other option to preserve the child's safety (CRC Articles 7, 8, 9, and 18).

Social work scholars have also discussed the global economic inequalities that provide people in one country the funds to adopt a child from another country whose parent has surrendered the child due to poverty or to remove a few select children from these circumstances while leaving the conditions unchanged (Freundlich 2000; Hollingsworth 2003; Rotabi et al. 2015a, b). Hollingsworth (2003) notes that adoption can exploit familial poverty in impoverished countries to the benefit of adopting families from wealthier nations. While it can provide goods and opportunities to those children who are adopted, it leaves the vast majority in unjust social structures. Social workers have called for action in addressing the global inequalities, as well as ethical problems underlying intercountry adoption practice (Gibbons and Rotabi 2012; Roby et al. 2013). Issues of adoption trafficking have occurred in a number of countries and include deception of birthmothers and purchasing/kidnapping of children (Cheney 2014a; Gibbons and Rotabi 2012; Mapp 2014; Rotabi and Bromfield 2017). Some countries, such as Guatemala, entered into an intercountry adoption moratorium after a number of years of serious and persistent human rights abuses in the system, including brazen child abductions into adoption (see Mónico 2013). At the time of the enactment of the moratorium in 2008, international regulatory standards were finally implemented to safeguard the process of adoption to prevent child sales and abduction into adoption (Cheney 2014b; Rotabi 2014; Rotabi and Mónico 2016; Rotabi and Gibbons 2012). This change was the result, ultimately, of the implementation of Hague Convention, and its protections, conceptualized as safeguards, have helped to reduce the number of inappropriate children moving to intercountry adoption.

The Hague Convention builds on the protections outlined in the CRC and, as of 2017 , had been signed by
98 states (Hague Conference on International Private Law $[\mathrm{HCCH}] 2016 \mathrm{a}, \mathrm{b})$. The Hague Convention is an international private law developed to prevent the sale and abduction of children in the intercountry adoption process (HCCH 1993). The best interest of the child is the central principle, and the regulatory standards instituted are recognized to be important steps forward in improving global intercountry adoption systems (Cheney 2014b; Gibbons and Rotabi 2012; Roby and Maskew 2012; Rotabi and Gibbons 2012). Fundamentally, the HCIA institutes ethical standards and safeguards to prevent force, fraud, and coercion in adoption. This protects the rights of orphaned and vulnerable children and both their birth and adoptive families (Rotabi and Gibbons 2012).

A number of the rights that are preserved by the HCIA are also found in the UN CRC. Specifically, the CRC shares with the HCIA the best interests principle, as identified in Article 3, stating "The best interests of children must be the primary concern in making decisions that may affect them. All adults should do what is best for children. When adults make decisions, they should think about how their decisions will affect children ..."(UNICEF n. d.). Like the CRC, the HCIA is oriented to maintaining children's care within their biological families, kinship group and communities. The HCIA provides a continuum of care based in Article 21 of the CRC called the subsidiarity principle so that the child's biological and kinship family life is preserved whenever possible. When adoption is appropriate and/or necessary, the preference is for domestic adoption, and other alternative care strategies are also explored to include child guardianship as appropriate options prior to a child being released for intercountry adoption (HCCH 2008).

Framed from a child rights perspective, the HCIA ultimately safeguards the process of adoption as countries of (child) origin and (child) destination countries agree to collaborate together within the regulatory framework to preserve child and family rights and ultimately ensure the best interests of the child in adoption decisions. The CRC identifies in Article 7 that, "Every child has the right to a name, a nationality, and to know and be cared for by her or his parents," and Article 8 states that "Every child has a right to preserve her or his identity, including nationality, name, and family relations." If and when it is determined that adoption is appropriate, the HCIA stipulates that birth family has the right to the following:

(1) receive unbiased counseling prior to legal consent for adoption, particularly being informed of the legal impact the adoption decree may have on any future parent-child relationship (Article 4c[1]);

(2) give informed consent in writing with unbiased witnesses (Article 4c[2]) and without financial incentives (Article 4c[3]); and 
(3) consent only after childbirth rather than planning for adoption before labor and delivery (Article 4c[4]).

These criteria for ethical adoption are provided here to illustrate the guidance provided by the HCIA to safeguard the process and to guarantee that only competent authorities engage in the adoption process. To be clear, this ensures the best interests of the child while protecting the parent(s) during this very vulnerable process of relinquishment. When there is no parent available to counsel, in the case of child abandonment, guidance also exists for ethical decision-making (HCCH 2008).

There has been a substantial decrease in intercountry adoptions to common receiving countries such as Australia, Canada, Spain, the United Kingdom, and the United States in recent years. The United States alone has seen a decrease of over 70\% since the all-time high of 22,991 children in 2004 (Selman 2015). Experts agree that the decline is related to an array of efforts undertaken to strengthen child welfare systems and ultimately promote ethical adoption practices in addition to moratoriums in countries like Guatemala where there was a clear pattern of child sales and abduction (Mónico 2013; Rotabi and Mónico 2016). Controls in the process of regulation have improved systems. For example, the United States' accreditation of adoption agencies has provided important oversight. While the HCIA is not a panacea and experts recognize that problems still exist, the improvements made have decreased illicit adoptions (Ballard et al. 2016; Rotabi and Gibbons 2012).

\section{The Growth of Commercial Global Surrogacy}

Like adoptions and adoption agencies, CGS is often "arranged" by organizations that call themselves fertility clinics often run by medical professionals with legal counsel in oversight of the process; alternatively attorneys coordinating with fertility services oversee the processes similar to some attorneys facilitating private adoptions. It should be underscored that these are private transactions in the United States (the most popular country for the service in the world) with little government/regulatory oversight. Today, a demand to build families through alternative means continues to grow, especially as the number of children adopted across international borders has been falling. While the actual number of surrogacy contracts is unknown, the number of children conceived through commercial global surrogacy has been growing in many countries (Cuthbert and Fronek 2014). Even with rapid growth and more and more children crossing borders in global transactions, there are currently no international laws that protect the parties to surrogacy arrangements, as the Hague Convention does for intercountry adoption (Scherman et al. 2016). Globally, national laws vary greatly, sometimes even within nations, such as in the United States and Australia. In the case of these two countries, they are geographically large and each state regulates surrogacy contracts within its own jurisdiction.

There is no reliable estimate of the number of surrogate births that occur each year globally, as countries tend not to record them separately from other births (Cheung 2014). In other words, birth certificates do not note the fact of a surrogacy contract and the private industry does not report activities to any sort of oversight body; fundamentally, commercial surrogacy has been treated as a private concern globally with little to no legal regulation/oversight of the process (Rotabi and Bromfield 2017). This neoliberal policy framework has allowed for a global marketplace to set the standards — or lack thereof (Bromfield and Rotabi 2014).

A number of social work scholars have addressed concerns about the vulnerability of parties to CGS arrangements, above and beyond the earlier mentioned statements by the BASW and IFSW (e.g., see Bromfield and Rotabi 2014; Fronek and Crawshaw 2015; Karandikar et al. 2014; Rotabi et al. 2015a). Ethical issues arise, as in India, where a surrogacy industry rapidly developed as part of the state's promotion of medical tourism (Deomampo 2013). Some surrogates have been recruited using questionable means (Nadimpally and Majumdar 2017), and concerns about informed consent included problems related to surrogates signing documents that they could not read (due to illiteracy or because they were written in another language, such as English). Many of the surrogates were kept guarded during their pregnancies in dormitories in order to monitor their health and nutrition daily. Such methods resemble those used by human traffickers in cases of CGS arrangements that are deceptive; in which, women are removed from their communities, their movements are controlled, and their exploitation is based on poverty, limited opportunity, and inadequate social protections and law enforcement in a context of violence against women (Rotabi and Bromfield 2012).

However, these concerns should be qualified with research conducted directly with Indian surrogates themselves. There is a small but robust body of (largely anthropological) empirical literature that focuses on Indian women who have acted as surrogate mothers. These women consistently report the practice to be an entrepreneurial opportunity for which they desire to see regulation that protects CGS as work or labor (Goswami et al. 2014; Karandikar et al. 2014; Pande 2014). A small qualitative study $(n=15)$ of Indian surrogate women (Karandikar et al. 2014) revealed that their vulnerabilities include stigma of work, that can be interpreted to be a part of the sex industry. While research indicates that the surrogate mothers themselves are clear that the work is not prostitution (see Pande 2014), there are certainly misunderstandings of the nature of a surrogacy contract. One key concern is the free will - self-determination — of women to participate in such an 
activity when they are living in extreme poverty (Rotabi and Bromfield 2017).

Pande (2014) thus encouraged a regulatory approach oriented toward fair labor practices as a result of her research in India. Goswami et al. (2014) specifically asked 25 surrogate mothers in India if they felt "used" or "taken advantage of"; all 25 women reported that they did not see themselves as being exploited - some were quite explicit that they saw the gain as their own or mutual in a win-win as they were paid for a service and a couple received a child (Rotabi and Bromfield 2017). Such perspectives need to be taken into account in the establishment of any regulatory frameworks.

\section{Existing National Regulations on the Practice of Commercial Surrogacy}

The first CGS story ever to gain international attention was the case of Baby Cotton in the mid-1980s. This case-which involved three countries: Sweden, the United States, and the United Kingdom - catalyzed the laws that prohibit CGS in the United Kingdom today (Cotton and Winn 1985). With the facilitative help of a surrogacy clinic in England, surrogate mother Kim Cotton (a British citizen) gave birth to an infant for a Swedish couple living in the United States. In this case, Kim Cotton was a traditional surrogate mother as her egg was used and artificially inseminated by the commissioning father's sperm (Cotton and Winn 1985).

When the UK authorities became aware of the case, they immediately stepped in and the infant became a ward of the court while the long-term custody outcome was deliberated (Cotton and Winn 1985). There was no contest of custody by those engaged in the contract - the surrogate mother took no interest in parenting the child. The case offended the sensibilities of the British authorities as well as the general public as the interface of technology (in vitro fertilization) and the creation of a human being as a contractual arrangement in which money changed hands was simply disturbing for many in the UK. Eventually, the Swedish intended parents were able to take the baby back to the United States (their country of residence) with the agreement that the child would not have contact with her surrogate mother (Cotton and Winn 1985).

In the end, the UK banned all surrogacy arrangements except for altruistic surrogacy. The Surrogacy Arrangements Act 1985 outlines relatively strict criteria, thereby making the UK a difficult country in which to arrange a surrogacy: there are not many women willing to engage in the activity as an altruistic endeavor (Crawshaw et al. 2012). Most Western European countries have followed suit, while some countries, such as France, have banned the practice of surrogacy altogether. This has created a scenario that has pushed Europeans to seek surrogacy services elsewhere.

As discussed earlier, one location that became attractive as a surrogacy destination was India. Commercial surrogacy became legal in India in 2002 (Malhotra and Malhotra 2013; SAMA 2012); it became a primary destination for the practice due to the low cost and government encouragement of medical tourism (Deomampo 2013). However, due to ethical concerns (discussed below), India effectively shut down the practice in 2015 pending a ruling by the Indian Supreme Court (Najar 2015; Rotabi and Bromfield 2017). In 2016, a bill was proposed that would ban commercial surrogacy and only allow altruistic surrogacy in limited circumstances (Lakshmi 2016). In 2017, the legal circumstances remain in limbo, with no ruling being made thus far, and the future remains uncertain.

Thailand and Cambodia, which also became increasingly involved following India's success, have also banned CGS due to recent scandals ("Cambodia bans surrogacy" 2016). In the United States, approximately half of the 50 states have legislation relating to surrogacy. Four ban commercial surrogacy completely-New York, New Jersey, Indiana, and Michigan, while 14 states regulate and permit some type of commercial surrogacy (Columbia Law School Sexuality \& Gender Law Clinic 2016). Most notably, California is recognized as a surrogacy-friendly jurisdiction with contractual procedurals favoring the individual/couple paying for a service. In California, such a contractual arrangement will cost in the range of US\$75,000-100,000 (Rotabi and Bromfield 2017).

With the closure of India at this juncture, the U.S. is now undeniably the most active commercial global surrogacy location in the world, as there are few other options available. It should be mentioned that the practice in California and elsewhere is most commonly a gestational surrogacy in which an embryo (that is not related to the surrogate) is transferred to the surrogate mother. The lack of genetic relationship (hence called a gestational surrogacy rather than a traditional surrogacy) is one of the hallmarks of CGS as it is practiced in most cases today. Prior to the shutdown of Indian CGS, gestational surrogacy was the only legal manner in which the surrogacy contract was allowed (Pande 2014).

The lack of regulation in gestational surrogacy practices, in what is now a billion dollar business, has resulted in discourse about how a country that allows CGS services interfaces legally with a second country where the consumer resides (Cheney 2014a; Darnovsky and Beeson 2014; Pande 2014; Rotabi 2014; Rotabi and Bromfield 2017). Such concerns are often referred to as "cross border" issues when considering laws and the debates that have occurred when more than one 
country is involved in determining the best interests of the child, especially when a CGS case is problematic or gets caught in a legal limbo. The idea behind the Hague Convention structure is a harmonization of laws and policies between two or more countries to avoid scenarios in which children as well as the adults involved are not able to obtain their human rights. Therefore, a discussion of child rights and some of the abuses that have occurred in CGS arrangements is needed.

\section{Child Rights and Commercial Global Surrogacy}

Most commonly, the child's rights that are considered to be placed at risk by commercial surrogacy are as follows: (1) the right to a nationality and to know one's parents/origin (Article 7) and (2) the right to preserve one's identity (Article 8), and not to be sold or trafficked (Article 35) (Blauwhoff and Frohn 2016). In addition, since CGS typically requires adoption of the newborn by one or both commissioning parents, Article 21 with its right "that the adoption of a child is authorized only by competent authorities," is violated since the parents do not undergo the preparation processes of ethical adoptions to include a home study. This particular point was made clear by the Baby Gammy case, which resulted in worldwide outrage when an Australian couple was believed to have left their surrogate-born son behind in Thailand because he was born with Down syndrome while they returned home with his healthy twin sister (though the court subsequently ruled that this was not the case, that the surrogate mother chose to keep him). The case gained further attention when it was learned that the commissioning father had a child sex offense history (Jabour 2014). This case was a catalyst for a moratorium on CGS in Thailand where the surrogacy was contracted (Head 2015).

When discussing the right to know one's parents, it is important to note that there can be up to five parents in a surrogacy arrangement: an egg provider, a sperm provider, a gestational mother, and two intended parents. No records are typically kept of the surrogate and the gamete donor, leaving only the commissioning parents to be known by the child, raising the question of whether this fulfills the intent of the CRC.

There has been debate over whether commercial surrogacy constitutes sale of a child or not. Some argue that the payments to surrogates, which may far exceed what they may earn through other means, constitutes sale of a child, and thus trafficking. Others note that this payment is not for the child, but for the surrogate mother's services (see Pande 2014 for the discussion of work and surrogacy). Additionally, some scholars state that the intent of the prohibition on the sale of a child is to prevent harm and exploitation, and since the intent of surrogacy is not for that purpose, it does not fall under the CRC (Gerber and O’Byrne 2015) nor under anti-trafficking laws. However, the Optional Protocol on the sale of children, Article 2(a) states that, "sale of children means any act or transaction whereby a child is transferred by any person or group of persons to another for remuneration or any other consideration" (italics added). As noted by Tobin (2014), the term "any act" does not simply focus on purposes of exploitation, but it is inclusive of any purpose for which a child is transferred for compensation.

While violation of these rights seems theoretical, there have been cases that have made the press where such violations have occurred above and beyond the Baby Gammy and Baby Cotton cases. There have been a number of instances in which the surrogacy took place in a country where it was legal, but the parents were from a country where commercial surrogacy was illegal and the parents then faced difficulties in bringing the child back to their native country, which would have rendered the child both parentless and stateless.

For example, in the Mennesson and Labassee cases, French commissioning parents had children born to surrogates in the U.S. where the children were genetically related to the commissioning father, but not the commissioning mother. As surrogacy is against French law, the French authorities refused to recognize the birth certificates with the commissioning parents as the legal parents and thus the children were not able to be French citizens. Upon reaching the European Court of Human Rights, the court ruled that while the CRC had not been violated, France had violated the right to respect of private life in the European Convention on Human Rights (Achmad 2014; Blauwhoff and Frohn 2016).

Other families who have commissioned a child in India have run afoul of the laws in their home country when they sought to bring the child home. A German couple, Jan Balaz and Susan Anna Lohlad, fought for 2 years to bring their surrogate twin sons home as German law did not recognize surrogacy as a means to establish parenthood and would not grant the travel document. Germany agreed to grant the documents after the couple went through the intercountry adoption process ("German surrogate twins to go home," 2010). A Norwegian citizen, Kari Ann Volden, encountered the same problem when attempting to get documents for her surrogate twins, as Norwegian laws established the Indian surrogate as the parent, while India stated that the commissioning person was the parent, leaving the twins stateless for 2 years until Volden was able to adopt them (Batha 2014; "Stateless twins live in limbo" 2011).

The case of Baby Manji also received substantial press attention. Baby Manji's Japanese commissioning parents divorced a month before his birth via an Indian surrogate. Since Japanese law does not recognize surrogacy, it appeared that the father, who was also the genetic father, would have to adopt Baby Manji; however, India law does not allow adoption by single men. The father was also unable to get a birth certificate as there was no legal mother. Normally, the commissioning mother is listed as the 
mother, but there was no longer a commissioning mother. India finally allowed the birth certificate to be issued with no mother's name (Points 2009).

These cases help to illustrate the need for an international law that protects all involved as national laws (of two different countries) can clearly conflict with each other, leaving the child in limbo. Parentage has been a significant consideration in looking at the way forward in developing international regulation as it broadens the framework to consider family system with greater orientation to child rights. For example, the Hague Conference on International Private Law has looked at the issues of developing an international private law in oversight of CGS practices in cross-border surrogacy arrangements (Hague Conference on International Private Law 2012) and their expert working group has identified that parentage is a critical component in any future policy-making process (Hague Conference on International Private Law 2016a, b). However, the policy development process for regulation is a very slow one and if a new law is fully developed and put forth to a vote, the law-making process is predicted to take years while the practice continues.

In the interim, advances may be made on a country-bycountry basis. Australia now appears to be taking leadership in developing guidelines for practice in response to the Baby Gammy case (Commonwealth of Australia 2016; International Social Service-Australia 2016) along with the International Social Services (ISS) General Secretariat. This latter organization, based in Switzerland, is formulating a child rights approach for policy advocacy by developing guidelines for CGS on a global scale. Thus far, Australia's ISS states that a convention regulating surrogacy must be developed and include the following safeguards (ISS of Australia 2015, p. 9):

- Cross-jurisdictional recognition of birth certificates and parentage orders

- Provisions to ensure the informed consent of surrogates

- Processes for counseling, education, and legal advice for all parties relating to psychosocial, legal, and medical issues

- Measures for the screening and assessment of suitability of intending parents and surrogates, including criminal and child protection history

- Measures to collect and preserve information to facilitate the surrogate-born child's future access to information regarding origins and identity

- Operational standards for surrogacy service providers

- Medical standards for the care of the surrogate-born child and surrogate mothers

- Measures in the event of the breakdown of the surrogacy arrangement, the intending parents' relationship, multiple births, or child disability

- Regulation of financial transactions so as not to constitute sale of a child
- Measures to guard against child trafficking

- Measures to prevent trafficking of women for surrogacy

These safeguards are consistent with previous suggestions from others. For example, Fronek and Crawshaw (2015) proposed procedures similar to those utilized in child adoption, including home studies and other practical aspects of social care, in this relatively new form of constructing families. Bromfield and Rotabi (2014) describe a pragmatic approach to regulating CGS, including the need to accredit fertility service providers as well as develop protocol for consent processes with an orientation to protections of women - including the serious problems related to women living in poverty and entering into CGS for the opportunity of work and profit as an entrepreneurial activity. Also, Bromfield and Rotabi (2014) outline the need for appropriate health insurance for surrogate mothers, especially for post-delivery medical needs in addition to life insurance in the case of death of the mother due to medical complications (also see Rotabi and Bromfield 2017). Other recommendations have been made by these social work professionals and others about informed consent processes, as well as issues of unbiased counseling of women in regards to the various risks of CGS (Karandikar et al. 2014).

\section{A Call for Action for International Regulation of Commercial Global Surrogacy}

It is clear from the history of ethical issues that have arisen as a result of CGS and conflicting national laws, that an international private law must be developed. This law must protect the interests of all parties, but especially the most vulnerable: the resulting child. By utilizing a child rights framework, the industry can be regulated to prevent human rights abuses and all forms of exploitation.

While there has been critical thinking and position development thus far within the discipline of social work and ISS, it is imperative that social workers take the lead in advocating for a legal framework to be developed in order to uphold human rights. When considering steps and the profession's involvement, authors Crawshaw and Fronek (2014), from the United Kingdom and Australia, state that "Social work can and should ... contribute to knowledge, and respond to potential harms and benefits of global and domestic reproductive practices that are charging ahead of legislative and other protections and ethical debates" (p. 6-7). Social workers must be educated about the human rights issues and begin to take on leadership in this area of reproductive technology, regardless of nationality. However, it can be particularly important for U.S. social workers given the frequency of the activity now in a number of states, including California. If international law is not developed, further violations of children's human rights will inevitably occur. 
However, it should be said that the HCIA is recognized by intercountry adoption experts to be far from perfect and exploitation still continues in many countries around the world (Ballard et al. 2016). Despite this, it must be recognized that the collaboration and cooperation that have resulted from the HCIA implementation is a clear strength - it is imperative that countries begin to collaborate effectively for cross-border surrogacy in order to harmonize regulatory procedures at the least, and at best, begin to institute consistent legal frameworks globally. At this juncture, the improvements have been very much seen in the regulation of adoption agencies in countries like the United States, which now must be accredited to operate (Rotabi and Bromfield 2017; Rotabi and Gibbons 2012), and requirements for accreditation of fertility clinics and other providers in the surrogacy transaction must be a priority as systems transform to be more ethical in all aspects of the service sector. Such an approach is critical in securing the rights of all involved in the transaction (Rotabi et al. 2015a, b). For social work as a human rights profession, it is incumbent upon us to prevent child rights violations and act in the best interests of the child.

\section{References}

Achmad, C. (2014). Children's rights to the fore in the European Court of Human Rights' first international commercial surrogacy judgments. European Human Rights Law Review, 6, 638-646.

Ballard, R., Goodono, N., Cochran, R., \& Milbrandt, J. (2016). The intercountry adoption debate: dialogues across disciplines. Newcastle upon Tyne: Cambridge Scholars Publishing.

Batha, E. (2014). International surrogacy traps babies in stateless limbo. Reuters. Retrieved from http://uk.reuters.com/article/us-foundationstatelessness-surrogacy-idUKKBN0HD19T20140918.

Blauwhoff, R., \& Frohn, L. (2016). International Commercial Surrogacy Arrangements: The Interests of the Child as a Concern of Both Human Rights and Private International Law. In C. Paulssen, T. Tacacs, V. Lazic, \& B. van Rompuy (Eds.), Fundamental Rights in International and European Law (pp. 211-241). TMC Asser Press: The Hague.

British Association of Social Workers (2016). BASW position statementSurrogacy. Retrieved from https://www.basw.co.uk/resource/?id= 5356.

Bromfield, N., \& Rotabi, K. (2014). Global surrogacy, exploitation, human rights and international private law: a pragmatic stance and call for meaningful international regulation. Global Social Welfare, 1(3), $123-135$.

Cambodia bans surrogacy (2016). Thai Law Forum. Retrieved from http://www.thailawforum.com/cambodia-bans-surrogacy/.

Cheney, K. E. (2014a). Executive summary of the International Forum on Intercountry Adoption and Global Surrogacy. ISS Working Paper Series/General Series (Vol. 596, pp. 1-40). International Institute of Social Studies of Erasmus University (ISS). Retrieved from http:// hdl.handle.net/1765/77408.

Cheney, K. E. (2014b). Giving children a 'better life'? Reconsidering social reproduction and humanitarianism in intercountry adoption. European Journal of Development Research, 26, 247-263.
Cheung, H. (2014). Surrogate babies: where can you have them, and is it legal? $B B C$. Retrieved from http://www.bbc.com/news/world28679020.

Columbia Law School Sexuality \& Gender Law Clinic (2016). Surrogacy law and policy in the U.S.: a national conversation informed by global lawmaking. Retrieved from http://www.law.columbia.edu/ sites/default/files/microsites/gender-sexuality/files/columbia sexuality and gender law_clinic_-_surrogacy_law_and policy report_- june_2016.pdf.

Commonwealth of Australia, House of Representatives, Standing Committee on Social Policy and Legal Affairs (2016). Surrogacy matters: inquiry into the legislative and regulatory aspects of international and domestic surrogacy arrangements. Retrieved from http://www.aph.gov.au/Parliamentary_Business/Committees/ House/Social_Policy_and_Legal_Affairs/Inquiry_into_surrogacy/ Report.

Cotton, K., \& Winn, D. (1985). Baby Cotton: for love and money. London: Gollancz Publications.

Crawshaw, M. (2016). What social workers need to know about surrogacy. The Guardian. Available from https://www.theguardian.com/ social-care-network/social-life-blog/2016/dec/14/what-socialworkers-need-to-know-about-surrogacy.

Crawshaw, M., Blythe, E., \& van den Akker, O. (2012). The changing profile of surrogacy in the UK-implications of national and international policy and practice. Journal of Social Welfare and Family Law, 34(3), 265-275.

Cuthbert, D., \& Fronek, P. (2014). Perfecting adoption? Reflections on the rise of commercial offshore surrogacy and family formation in Australia. In Families, policy and the law. Australian Institute of Family Studies: Australian Government.

Darnovsky, M., \& Beeson, D. (2014). Global surrogacy practices. In K. E. Cheney (Ed.), ISS working paper series/general series (Vol. 601, pp. 1-54) Retrieved from http://hdl.handle.net/1765/77402.

Deomampo, D. (2013). Gendered geographies of reproductive tourism. Gender \& Society, 27(4), 514-547.

Fong, R., McRoy, \& McGinnis, H. (2016). Overview of intercountry adoptions. In R. Fong \& McRoy (Eds.), Transracial and intercountry adoptions: cultural guide for professionals (pp. 19-37). New York: Columbia University Press.

Freundlich, M. (2000). Market forces: the issues in international adoption. In M. Freundlich (Ed.), Adoption and ethics (pp. 37-66). Washington: Child Welfare League of America.

Fronek, P., \& Crawshaw, M. (2015). The 'new family' as an emerging norm: a commentary on the position of social work. British Journal of Social Work, 45(2), 737-746. doi:10.1093/bjsw/bct198.

Gibbons, J. L., \& Rotabi, K. S. (Eds.). (2012). Intercountry adoption: policies, practices, and outcomes. Surrey: Ashgate Press.

Gerber, P., \& O'Byrne, K. (2015). Souls in the house of tomorrow: the rights of children born via surrogacy. In P. Gerber \& K. O'Byrne (Eds.), Surrogacy law and human rights (pp. 81-112). Burlington: Ashgate.

German surrogate twins to go home (2010). The Times of India. Retrieved from http://timesofindia.indiatimes.com/india/German-surrogatetwins-to-go-home/articleshow/5978925.cms.

Goodwin, M. B. (2010). Baby markets: money and the new politics of creating families. New York: Cambridge University Press.

Goswami, L., Rotabi, K.S., \& Bromfield, N.F. (2014). Force, fraud, coercion and exploitation: Abuses in intercountry adoption contrasted against what Indian women acting as surrogate mothers have to say about their experiences. Paper presented at the International Forum on Intercountry Adoption and Global Surrogacy, The Hague, Netherlands.

Hague Conference on International Private Law [HCCH] (2012). A preliminary report on the issues arising from international surrogacy arrangements. Retrieved from http://www.hcch.net/upload/wop/ gap2012pd10en.pdf. 
Hague Conference on International Private Law [HCCH] (2016a). Status table. Retrieved from https://www.hcch.net/en/instruments/ conventions/status-table $/$ ?cid $=69$.

Hague Conference on International Private Law [HCCH] (2016b). Report of the February 2016 experts group meeting on parentage/ surrogacy. Retrieved from https://assets.hcch.net/docs/192c95b54364-4461-bb04-2382e3c0d50d.pdf.

Hague Conference on Private International Law [HCCH]. (1993). Convention of 29 May 1993 on Protection of Children and Co-Operation in Respect of Intercountry Adoption. Retrieved from http://www.hcch.net/index_en.php?act=conventions. text\&cid=69.

Hague Conference on Private International Law [HCCH] (2008). The implementation and operation of the 1993 Hague Intercountry Adoption Convention: guide to good practice. Retrieved from http://www.hcch.net/upload/wop/ado pd02e.pdf.

Head, J. (2015). Thailand bans commercial surrogacy for foreigners. $B B C$ News. Retrieved from http://www.bbc.com/news/world-asia31546717.

Hollingsworth, L. D. (2003). International adoption among families in the United States: considerations of social justice. Social Work, 48(2), 209-217.

International Federation of Social Workers (2012). Cross border reproductive services. Retrieved from http://ifsw.org/policies/crossborder-reproductive-services/.

International Social Services of Australia (2016). Who we are. Retrieved from http://www.iss-ssi.org/index.php/en.

International Social Services of Australia (2015). Submission to the Senate inquiry into regulatory and legislative aspects of international and domestic surrogacy arrangements. Retrieved from http:// www.iss.org.au/our-publications/major-reports/.

Jabour, B. (2014). Baby Gammy: conflicting reports about baby boy "abandoned" in Thailand. The Guardian. Retrieved from http:// www.theguardian.com/world/2014/aug/04/baby-gammyconflicting-reports-about-baby-boy-abandoned-in-thailand.

Karandikar, S., Gezinski, L. B., Carter, J. R., \& Kaloga, M. (2014). Economic necessity or a noble cause? Exploring motivations for gestational surrogacy in Gujarat, India. Affilia, 29(2), 224 236

Lakshmi, R. (2016). India to propose a ban on commercial surrogacy, ending a lucrative business. The Washington Post. Retrieved from https:/www.washingtonpost.com/world/rent-a-womb-industry-inindia-may-be-shut-down/2016/08/24/39684d60-79e3-42c9-893d9ff5998ce179 story.html?utm term=.a4d3d0a0e5b6\#.

Malhotra, A., \& Malhotra, R. (2013). Surrogacy: imported from Indiathe need for a regulatory law. In International Social Services/ International Reference Center Team (Eds.) ISS Monthly Review (Special Issue): The International Resort to Surrogacy: A New Challenge to be Addressed Urgently (pp. 8-9). Geneva: International Social Services.

Mapp, S. C. (2014). Human rights and social justice in a global perspective: An introduction to international social work (2nd ed.). New York: Oxford University Press.

Mónico, C. (2013). Implications of child abduction for human rights and child welfare systems: a constructivist inquiry of the lived experience of Guatemalan mothers publically reporting child abduction for intercountry adoption. (Doctoral dissertation). Available from VCU Digital Archives, Electronic Theses and Dissertations, http://hdl. handle.net/10156/4373.

Nadimpally, S., \& Majumdar, A. (2017). Recruiting to give birth: agent-facilitators and the commercial surrogacy arrangements in India. In M. Davies (Ed.), Babies for sale (pp. 48-68). London: Zed Books.

Najar, N. (2015). India wants to ban birth surrogacy to foreigners. New York Times. Retrieved from http://www.nytimes.com/2015/10/29/ world/asia/india-wants-to-ban-birth-surrogacy-for-foreigners. html? $\mathrm{r}=0$.

Pande, A. (2014). Wombs in labour: transnational commercial surrogacy in India. New York: Columbia University Press.

Points, K. (2009). Commercial surrogacy and fertility tourism in India: the case of Baby Manji. Kenan Institute for Ethics at Duke University. Retrieved from https://web.duke.edu/kenanethics/ casestudies/babymanji.pdf.

Roby, J. L. (2007). From rhetoric to best practice: children's rights in intercountry adoption. Children's Legal Rights Journal, 27(3), 48-71.

Roby, J. L., \& Maskew, T. (2012). Human rights considerations in intercountry adoption: The children and families of Cambodia and Marshall Islands. In J. L. Gibbons \& K. S. Rotabi (Eds.), Intercountry adoption: Policies, practices, and outcomes (pp. 5566). Surrey: Ashgate Press.

Roby, J. L., Rotabi, K. S., \& Bunkers, K. M. (2013). Social justice and intercountry adoptions: the role of the U.S. social work community. Social Work, 58(4), 295-303. doi:10.1093/sw/swt033.

Rotabi, K. S. (2014). Force, fraud, and coercion: bridging from knowledge of intercountry adoption to global surrogacy. In K. E. Cheney (Ed.), ISS Working Paper Series/General Series (Vol. 600, pp. 1-30). International Institute of Social Studies of Erasmus University (ISS). Retrieved from http://hdl.handle. net/1765/77403

Rotabi, K. S., \& Bromfield, N. F. (2012). Intercountry adoption declines lead to new practices of global surrogacy in Guatemala: Global human rights concerns in the context of violence and the era of advanced fertility technology. Affilia, 27(2), 129-141. doi:10.1177/ 0886109912444102

Rotabi, K. S., \& Bromfield, N. F. (2017). From intercountry adoption to global surrogacy: a human rights history and new fertility frontiers. Abingdon: Routledge.

Rotabi, K. S., \& Bunkers, K. M. (2011). In the era of reform: a review of social work literature on intercountry adoption. Sage Open. doi:10. 1177/2158244011428160 Retrieved from http://sgo.sagepub. com/content/early/2011/11/14/2158244011428160.full\#aff-1. A podcast interview about this publication is available at $\mathrm{http}: / /$ sgo.sagepub.com/content/early/2011/11/14/2158244011428160/ suppl/DC1.

Rotabi, K. S., \& Gibbons, J. L. (2012). Does the Hague Convention on intercountry adoption adequately protect orphaned and vulnerable children and their families? Journal of Child and Family Studies, 21(1), 106-119. doi:10.1007/ s10826-011-9508-6.

Rotabi, K. S., \& Mónico, C. (2016). Intercountry adoptions: legal and policy issues affecting adoption practice. In R. Fong \& R. McRoy (Eds.), Transracial and intercountry adoptions: cultural guidance for professionals and educators (pp. 38-68). New York: Columbia University Press.

Rotabi, K. S., Bromfield, N. F., \& Fronek, P. (2015a). International private law to regulate commercial global surrogacy practices: just what are social work's practical policy recommendations? International Social Work, 58(4), 575-581.

Rotabi, K. S., Mónico, C. C., \& Bunkers, K. B. (2015b). At this critical juncture in the era of reform: reviewing 35 years of social work literature on intercountry adoption. In R. Ballard, N. Goodno, R. Cochran, \& J. Milbrandt (Eds.), The intercountry adoption debate: dialogues across disciplines (pp. 35-47). Newcastle upon Tyne: Cambridge Scholars Publishing.

SAMA-Resource Group for Women and Health (2012). Birthing a market: a study on commercial surrogacy. Retrieved from http://www. samawomenshealth.org/publication/birthing-market-\%E2\%80\% 98 commercial-surrogacy-india.

Scherman, R., Misca, G., Rotabi, K. S., \& Selman, P. F. (2016). Global commercial surrogacy and international adoption: parallels and differences. Adoption\& Fostering, 40(1), 20-35. 
Selman, P. F. (2015). Global trends in intercountry adoption, 2003-2012. In R. L. Ballard, N. Goodno, R. Cochran, \& J. Milbrandt (Eds.), The intercountry adoption debate: dialogues across disciplines (pp. 9 48). Newcastle upon Tyne: Cambridge Scholars Publishing.

Stateless twins live in limbo (2011). The Times of India. Retrieved from $\mathrm{http}: / /$ timesofindia.indiatimes.com/city/mumbai/Stateless-twinslive-in-limbo/articleshow/7407929.cms.
Tobin, J. (2014). To prohibit or permit: what is the (human) rights response to the practice of international commercial surrogacy. International and Comparative Law Quarterly, 63, 317-352.

UNICEF (n. d.). Convention on the Rights of the Child: Guiding principles. Available from http://www.unicef.org/crc/files/Guiding Principles.pdf. 